Brit. J. industr. Med., 1963, 20, 236.

\title{
AN AUTOPSY SURVEY OF BANTU SOUTH AFRICAN COAL-MINERS
}

\author{
BY \\ C. B. CHATGIDAKIS \\ From the Pneumoconiosis Research Unit, Council for Scientific and Industrial Research, Johannesburg
}

(RECEIVED FOR PUBLICATION NOVEMBER 29, 1962)

\begin{abstract}
An autopsy survey of 1,010 Bantu South African coal-miners has been carried out in order to ascertain the commonest causes of death and the incidence of cardiorespiratory tuberculosis and of coal-workers' pneumoconiosis. These are consecutive autopsy cases. By law, all miners who die from any cause whatsoever, while still employed by the mines immediately before death, must be autopsied, but few autopsies are performed on repatriated miners who die in their homes. For this reason a serious bias has taken place and this limits the possibility of generalizing from this paper. The commonest cause of death was multiple injuries. Primary carcinoma of the liver was the commonest malignancy and the incidence of bronchogenic carcinoma was low. These are the usual findings in the Bantu. Active tuberculosis of the respiratory organs was found in $12 \%$ of cases. Coalworkers' pneumoconiosis was present in $26.8 \%$, and $94 \%$ of these cases were of the simple type. There were only 17 cases of progressive massive fibrosis, and this is due to the fact that few autopsies were carried out on such cases. Active tuberculosis of the respiratory organs was present in $21 \%$ of cases with simple coal-workers' pneumoconiosis. The commonest cardiac lesion was chronic nonspecific adhesive pericarditis. Myocardial infarction was absent in this series but this is not unusual as infarction of the heart is rare in the Bantu.
\end{abstract}

The South African coal-mining industry employs a considerable number of Bantu labourers; 56,400 were employed in 1959. Forty per cent were recruited from Portuguese East Africa and the remainder from the Republic of South Africa and the adjacent territories of Basutoland, Bechuanaland, and Swaziland (Frazer, 1961). These recruits undergo medical and radiological examinations before being employed to exclude all but the physically fit. Employed in various capacities underground and on the surface, these workers serve for varying lengths of time. Little accurate information is available about the autopsy incidence and pattern of disease in this group of miners. To fill this gap the following autopsy survey was carried out. Particular attention has been paid to the incidence of coal-workers' pneumoconiosis and to tuberculosis of the cardiorespiratory organs.

\section{Material Studied}

This consisted of 1,010 autopsies on Bantu coal-workers performed during the period January, 1958, to June, 1961. By law, all miners who die from any cause whatsoever when still employed by the mines must undergo an autopsy.
This survey therefore includes all such cases and in addition a few miners who died in their homes following repatriation and where autopsy was specifically requested by the relatives. This introduces an unavoidable error of case selection. The majority of the autopsies were performed by various mine medical officers and district surgeons, and a few by the trained pathologists of the Pneumoconiosis Research Unit. This introduces an unavoidable variation in the standard performance of the general autopsy and the certified cause of death. However, the person performing the autopsy has, by law, to submit the cardiorespiratory organs, together with details of age, service record, and autopsy findings, to the Miners' Medical Bureau where macroscopic and microscopic examinations are performed by the trained pathologists of the Pneumoconiosis Research Unit. Such examinations are detailed and standardized, and were not subject to any variation during the period of this survey.

\section{Results of the Survey}

Age Incidence.-The ages of labourers are certified by the mine which employs the individual and are obtained during life by skilled interrogators in the worker's own language. They can be regarded as 
reasonably accurate. The age incidence of these autopsy cases is shown in Table 1.

TABLE 1

AGE INCIDENCE OF 1,010 BANTU COAL-WORKERS

\begin{tabular}{c|c}
\hline Age (years) & Number of Cases \\
\hline $16-19$ & 32 \\
$20-$ & 95 \\
$25-$ & 81 \\
$30-$ & 107 \\
$35-$ & 107 \\
$40-$ & 121 \\
$45-$ & 130 \\
$50-$ & 117 \\
$55-$ & 65 \\
$60-$ & 50 \\
$65-$ & 22 \\
$70+$ & 13 \\
Unknown & 70 \\
\hline Total & 1,010 \\
\hline
\end{tabular}

From Table 1 it is noted that 518 out of 940 cases $(55 \%)$ are 40 years and over and 267 out of 940 cases $(28 \%)$ are 50 years and over. This high percentage of cases 40 years and over in a Bantu autopsy survey in Africa is unusual. The majority of autopsy cases studied by Becker (1943), Higginson (1951), and Davies (1948) fall into the younger age groups.

The Causes of Death.-The causes of death of the 1,010 Bantu coal-miners are shown in Table 2.

TABLE 2

CAUSES OF DEATH OF 1,010 BANTU COAL-MINERS

\begin{tabular}{l|c}
\hline \multicolumn{1}{c|}{ Cause of Death } & No. of Cases \\
\hline Unnatural & 275 \\
(a) Multiple injuries & 210 \\
(b) Miscellaneous (drowning, burns, & 65 \\
electrocution, etc.) & 484 \\
\hline Natural & 91 \\
(a) Tuberculosis & 100 \\
(b) Primary pneumonia & 50 \\
(c) Diseases of the alimentary tract & 108 \\
(d) Diseases of the cardio-vascular system & 27 \\
(e) Diseases of the central nervous system & 21 \\
(f) Diseases of the kidneys & 52 \\
(g) Malignant disease & 35 \\
(h) Miscellaneous & 251 \\
\hline Not specified & \\
\hline
\end{tabular}

From Table 2 it is noted that the causes of death were specified in 759 cases only; of these 275 (36\%) died from various forms of violence such as mine and road accidents. The remaining 484 miners died of natural causes. Tuberculosis was responsible for 91 out of 759 deaths $(12 \%)$ (cf. Becker's (1943) series, $27 \%$ ). There is very little comparative literature on autopsy studies of tuberculosis in South African Bantu non-miners. Schrier (1948) found tuberculosis to be the cause of death in $6.6 \%$ of employees in one of the divisions in General Motors Corporation, and Lavenne (1960) in $13.7 \%$ of 338 Welsh coal-miners with pneumoconiosis. Primary pneumonia caused 100 out of 759 deaths in South African Bantu coalminers, and Vint (1937) found primary pneumonia to be the cause of death in $29.8 \%$ of East African natives. Cardiovascular disease was the cause of death in $13 \%$ of these coal-miners ( $c f$. Becker (1943), $11 \%$ ).

Malignant Disease.-Malignant disease accounted for 52 deaths $(7 \%)$. The types of malignant disease are shown in Table 3.

TABLE 3

TYPES OF MALIGNANT DISEASE IN 759 BANTU COAL-MINERS

\begin{tabular}{l|c}
\hline \multicolumn{1}{c|}{ Type of Malignant Disease } & No. of Cases \\
\hline Primary carcinoma of the liver & 32 \\
Bronchogenic carcinoma & 4 \\
Carcinoma of the bladder & 3 \\
Carcinoma of the oesophagus & 2 \\
Carcinoma of the pancreas & 3 \\
Carcinoma of the stomach & 1 \\
Carcinoma of the bowel & 2 \\
Miscellaneous & 5 \\
\hline \multicolumn{1}{c}{ Total } & 52 \\
\hline
\end{tabular}

In a recent survey of malignant disease in Bantu gold-miners the incidence of malignant disease was found to be $6.3 \%$ (Chatgidakis, 1960). Primary carcinoma of the liver was the commonest type of malignancy in these coal-miners, constituting $61 \%$ of all malignancies compared with $72 \%$ in Bantu gold-miners (Chatgidakis, 1960). In Berman's (1935) series of Bantu labourers on the Rand gold-mines primary carcinoma of the liver accounted for $90.5 \%$ of all malignancies. Only four cases of bronchogenic carcinoma occurred in these coal-miners, giving an autopsy incidence of $0.5 \%$, and $7.6 \%$ of all malignancies. In a recent survey of malignant disease in Bantu South African gold-miners, the autopsy incidence of bronchogenic carcinoma was $0.3 \%$, and $4 \%$ of all malignancies (Chatgidakis, 1960 ). Berman (1935) found at autopsy three cases of bronchogenic carcinoma amongst 358 mine labourers. Duchen (1954) found the autopsy incidence of bronchogenic carcinoma to be $3.8 \%$ in white males and $1.4 \%$ in African males. The details of the miners with bronchogenic carcinoma in this series are as follows:

(1) Age, 48 years. Service, 9 years. Large cell carcinoma arising from the right main upper lobe bronchus. No evidence of coal-workers' pneumoconiosis.

(2) Age, 58 years. Service, 12 years. Squamous carcinoma arising from the right main upper lobe bronchus. No evidence of coal-workers' pneumoconiosis. Active tuberculosis was present in the lungs.

(3) Age unknown. Service, unknown. Small cell carcinoma arising from the main bronchus of the right lower lobe. Simple pneumoconiosis was present. 
(4) Age, 59 years. Service, unknown. Squamous carcinoma of the right main bronchus. No evidence of coal-workers' pneumoconiosis.

Types and Incidence of Respiratory Tuberculosis. Evidence of tuberculosis was found in 257 cases in this series, an autopsy incidence of $27 \%$. Carnes of Johns Hopkins Hospital (1942), eliminating the fatal cases of tuberculosis in his series, found 147 out of 229 Negroes with tuberculous lesions (44\%) when a complete examination of the lungs and all lymph glands was done and in addition the $x$-ray films were examined. In this series of Bantu coal-miners, if the 91 fatal cases of tuberculosis were eliminated, the incidence of tuberculosis would be $19 \%$. Naegeli (1900), in 508 autopsies on persons 18 years and over, found healed, inactive, and active tuberculosis in the lungs of $93 \%$. Wason (1922), in 600 autopsies where no special effort was made to search for tuberculous lesions, "but pleura, apices of lungs and lymph nodes were noted", found an incidence of tuberculosis in $82 \%$ of adults 20 years and over. Todd in Edinburgh (1927) examined 404 cadavers and found evidence of tuberculosis in $69 \%$ of cases which had died of other diseases, and in 18 cases tuberculosis was the cause of death. Landé and Wolff of Washington Country Hospital (1941), with macroscopic examination only, found evidence of tuberculosis in $39.4 \%$ of 165 autopsies. Medlar (1955) examined fresh tissues from 1,332 bodies after sudden death and although a complete necropsy was performed in only about $20 \%$, he found necrotic or calcified lesions in 1,000 cases $(75 \%)$. Opie (1917), using $x$-ray plates to identify the less readily distinguishable nodules in the lung and hilar lymph nodes, found that after the age of 18 years $100 \%$ of bodies revealed lesions of tuberculosis. From a comparison of the above autopsy incidences it appears that the incidence of tuberculosis in this particular group of coal-workers is not exceptionally high.

The criteria used for the diagnosis of the various types of tuberculosis are as follows:-
1. Active tuberculosis. Non-encapsulated caseations; encapsulated caseation with non-granular cell reaction on the periphery or polymorphonuclear cell infiltration into the caseous material; acute inflammatory reaction showing the presence of acid-fast bacilli; tuberculous follicles.

2. Inactive tuberculosis. Encapsulated caseation with no cellular reaction on the periphery and no acid-fast bacilli. The caseous material may or may not show calcification. (Histoplasmosis and coccidioides are rare in this country.)

3. Healed tuberculosis. Complete fibrosis of the lesion with or without calcification.

The incidence of the various types of respiratory tuberculosis is shown in Table 4.

From Table 4 it is noted that active tuberculosis was the commonest type found, forming $45 \%$ of all tuberculous lesions and giving an autopsy incidence of $12 \%$. Macroscopic caseation in the hilar glands was noted in only 37 cases and no glands were grossly enlarged. Chronic tuberculous cavities are rarely found in the Bantu and in this series no case showed the presence of chronic cavities.

Calcification of Tuberculous Lesions.-Calcification occurred in 23 cases showing evidence of tuberculous lesions $(8.7 \%)$. Medlar (1955) states that calcified foci are frequently observed in adults. Opie (1917) stated that $98 \%$ of white adults dying of diseases other than tuberculosis have calcified tuberculous lesions, and calcification is less extensive in coloured than in white adults.

Coal-workers' Pneumoconiosis.-The main coal production areas in South Africa are situated in the Orange Free State, Transvaal, and Natal. The labour employed is mainly migratory. On the average, the Bantu labourer works about 12 to 15 months and then returns to his home for an average period of six to nine months before coming back for further employment, not necessarily at the same mine or

TABLE 4

INCIDENCE OF THE VARIOUS TYPES OF RESPIRATORY TUBERCULOSIS IN 1,010 BANTU COAL-MINERS

\begin{tabular}{|c|c|c|c|c|}
\hline Type of Tuberculosis & $\begin{array}{l}\text { No. of } \\
\text { Cases }\end{array}$ & $\begin{array}{l}\text { Autopsy } \\
\text { Incidence } \\
(\%)\end{array}$ & $\begin{array}{c}\% \text { of all } \\
\text { Tuberculous Lesions }\end{array}$ & $\begin{array}{l}\text { Calcification } \\
\text { (Cases) }\end{array}$ \\
\hline $\begin{array}{l}\text { Healed } \\
\text { (a) Hilar glands only } \\
\text { (b) Lungs }\end{array}$ & $\begin{array}{l}92 \\
76 \\
16\end{array}$ & 9 & 33 & 12 \\
\hline $\begin{array}{l}\text { Inactive } \\
\text { (a) Hilar glands only } \\
\text { (b) Lungs }\end{array}$ & $\begin{array}{l}59 \\
49 \\
10\end{array}$ & 12 & 21 & 10 \\
\hline $\begin{array}{l}\text { Active } \\
\text { (a) Hilar glands only } \\
\text { (b) Lungs }\end{array}$ & $\begin{array}{r}124 \\
30 \\
94\end{array}$ & 12 & 45 & 1 \\
\hline
\end{tabular}


even in the same class of work. The great majority are housed in compounds or single quarters equipped with communal feeding, health, and recreation services. About $3 \%$ of the labour force are housed with their families in married quarters adjacent to the compounds (Frazer, 1961). All South African collieries use the Bord and pillar system of mining. Water is used for dust suppression at all stages of work (Frazer, 1961), and more than half the coal produced is washed (4th Geological Survey, S. Africa, 1959). The greatest amount of coal produced in South Africa is bituminous (Walters, L. G., 1961 ; personal communication). Plumstead (1957) states that the whole bulk of the South African coal industry is based on bituminous coals of the late Paeleozoic Age and that there is no true anthracite in this country as none of the coal-bearing rocks have suffered lateral compression.

The various degrees of coal-workers' pneumoconiosis were as follows:-

1. Minimal. A moderate degree of coal-dust deposition in the lungs with foci of dust reticulinosis and a slight degree of emphysema related to the dust deposits.

2. Slight. A moderate to marked coal-dust deposition in the lungs with numerous foci of dust reticulinosis and a moderate to marked emphysema related to the dust deposits or palpable macule formation with a moderate to marked emphysema related to the dust deposits.

3. Moderate. Marked coal-dust deposition in the lungs with numerous palpable macules with or without foci of pigmented fibrosis of less than $2 \frac{1}{2} \mathrm{~cm}$. in diameter and a well-marked emphysema related to the dust deposits.

4. Marked (P.M.F.). Marked coal-dust deposition in the lungs with areas of massive fibrosis greater than $2 \frac{1}{2} \mathrm{~cm}$. in diameter and a well-marked emphysema related to the dust deposits.

There were 270 cases showing evidence of coal- workers' pneumoconiosis in the whole series, giving an autopsy incidence of $26.8 \%$. Of these, 253 cases were of the simple type (94\%) and 17 of progressive massive fibrosis. James and Thomas (1956). from an analysis of 1,000 Welsh coal-miners (1947 to 1950), found 546 cases of simple pneumoconiosis and 454 cases of massive fibrosis. It is obvious that in this series cases of massive fibrosis are poorly represented and this is due to repatriation of these miners and a consequent lack of autopsies. The histology of coalworkers' pneumoconiosis found in this series of cases does not differ in any way from the lesions described by Gough $(1946,1949)$.

Simple Coal-workers' Pneumoconiosis.-The age incidence correlated with the degree of simple coalworkers' pneumoconiosis is shown in Table 5 .

Statistical analysis of Table 5 indicates that the distribution of the various degrees of simple coalworkers' pneumoconiosis varies with the age. Minimal silicosis is present in three-quarters of the cases in the age group 25-44, half of these cases in the age group 45-64, and in less than two-fifths of these cases in the $65+$ age group.

The length of service of miners with simple coalworkers' pneumoconiosis correlated with the degree of pneumoconiosis is shown in Tables 6 and 7 .

From Table 7 it is noted that with increasing service the number of cases without pneumoconiosis falls and the frequency of a slight and a moderate

TABLE 6

LENGTH OF SERVICE CORRELATED WITH THE DEGREE OF SIMPLE COAL-WORKERS', PNEUMOCONIOSIS (PERCENTAGES OF TOTALS)

\begin{tabular}{c|c|c|c|c|c}
\hline \multirow{2}{*}{$\begin{array}{c}\text { Length of } \\
\text { Service } \\
\text { (years) }\end{array}$} & \multicolumn{2}{|c|}{ Degree of Coal-workers' Pneumoconiosis } & Total \\
\cline { 2 - 3 } & Nil & Minimal & Slight & Moderate & \\
\hline $0-4$ & $86 \cdot 1$ & $8 \cdot 2$ & $5 \cdot 1$ & $0 \cdot 7$ & $100 \cdot 1$ \\
$5-9$ & $59 \cdot 1$ & $24 \cdot 6$ & $14 \cdot 9$ & $1 \cdot 4$ & $100 \cdot 0$ \\
$15+5$ & $28 \cdot 6$ & $20 \cdot 4$ & $36 \cdot 7$ & $14 \cdot 3$ & $100 \cdot 0$ \\
Unknown & $69 \cdot 5$ & $19 \cdot 2$ & $9 \cdot 0$ & $2 \cdot 3$ & $100 \cdot 0$ \\
\hline
\end{tabular}

TABLE 5

AGE INCIDENCE CORRELATED WITH THE DEGREE OF COAL-WORKERS' PNEUMOCONIOSIS

\begin{tabular}{|c|c|c|c|c|c|}
\hline \multirow{2}{*}{$\underset{\text { (years) }}{\text { Age }}$} & \multicolumn{3}{|c|}{$\begin{array}{c}\text { Degree of } \\
\text { Coal-workers' Pneumoconiosis }\end{array}$} & \multicolumn{2}{|c|}{ Total } \\
\hline & Minimal & Slight & Moderate & No. & $\%$ \\
\hline $\begin{array}{l}25- \\
30- \\
35- \\
40- \\
45- \\
50- \\
55- \\
60- \\
65- \\
70+ \\
\text { Unknown }\end{array}$ & $\begin{array}{r}3 \\
10 \\
10 \\
29 \\
24 \\
20 \\
18 \\
13 \\
5 \\
2 \\
6\end{array}$ & $\begin{array}{r}3 \\
2 \\
3 \\
10 \\
14 \\
27 \\
8 \\
8 \\
11 \\
2 \\
7\end{array}$ & $\begin{array}{l}0 \\
1 \\
0 \\
1 \\
1 \\
1 \\
6 \\
7 \\
1 \\
0 \\
0\end{array}$ & $\begin{array}{r}6 \\
13 \\
13 \\
40 \\
39 \\
48 \\
32 \\
28 \\
17 \\
4 \\
13\end{array}$ & $\begin{array}{r}2.4 \\
5.1 \\
5.5 \\
15.7 \\
15.4 \\
18.9 \\
12.6 \\
11.0 \\
6.7 \\
1.6 \\
5.1\end{array}$ \\
\hline Total & 140 & 95 & 18 & 253 & $100 \cdot 0$ \\
\hline
\end{tabular}


TABLE 7

LENGTH OF SERVICE CORRELATED WITH THE DEGREE OF SIMPLE COAL-WORKERS' PNEUMOCONIOSIS

\begin{tabular}{|c|c|c|c|c|c|c|}
\hline \multirow{2}{*}{$\begin{array}{c}\text { Length of } \\
\text { Service } \\
\text { (years) }\end{array}$} & \multicolumn{4}{|c|}{ Degree of Coal-workers' Pneumoconiosis } & \multicolumn{2}{|c|}{ Total (Coal-workers' Pneumoconiosis) } \\
\hline & Nil & Minimal & Slight & Moderate & No. & $\%$ \\
\hline $\begin{array}{l}0-4 \\
5-9 \\
10-14 \\
15-19 \\
20+ \\
\text { Unknown }\end{array}$ & $\begin{array}{r}475 \\
100 \\
27 \\
10 \\
4 \\
124\end{array}$ & $\begin{array}{r}51 \\
25 \\
26 \\
5 \\
5 \\
28\end{array}$ & $\begin{array}{r}28 \\
17 \\
16 \\
7 \\
11 \\
16\end{array}$ & $\begin{array}{l}\mathbf{7} \\
\mathbf{2} \\
\mathbf{0} \\
\mathbf{0} \\
\mathbf{7} \\
\mathbf{2}\end{array}$ & $\begin{array}{l}86 \\
44 \\
42 \\
12 \\
23 \\
46\end{array}$ & $\begin{array}{r}34 \cdot 0 \\
17 \cdot 4 \\
16 \cdot 6 \\
4 \cdot 7 \\
9 \cdot 1 \\
18 \cdot 1\end{array}$ \\
\hline
\end{tabular}

degree of simple coal-workers' pneumoconiosis increases markedly.

Tuberculosis was the cause of death in 32 cases with simple coal-workers' pneumoconiosis, i.e. 32 out of 200 cases in which the cause of death was known $(16 \%)$. The type of tuberculosis found in these cases of simple coal-workers' pneumoconiosis and the incidence are shown in Table 8.

TABLE 8

INCIDENCE AND TYPE OF RESPIRATORY TUBERCULOSIS IN 253 CASES OF SIMPLE COAL-WORKERS PNEUMOCONIOSIS

\begin{tabular}{l|c}
\hline \multicolumn{1}{c|}{ Type of Tuberculous Lesion } & No. of Cases \\
\hline Active & 52 \\
(a) Hilar glands only & 11 \\
(b) Lungs & 45 \\
\hline Inactive & 26 \\
(a) Hilar glands only & 19 \\
(b) Lungs & 7 \\
\hline Healed & 57 \\
(a) Hilar glands only & 50 \\
(b) Lungs & 7 \\
\hline \multicolumn{2}{c}{ Total } \\
\hline
\end{tabular}

From Table 8 it is noted that 135 out of 253 cases $(53 \%)$ showed some evidence of tuberculosis in the respiratory system and in 80 out of $135(59 \%)$ the hilar glands alone were involved. Active tuberculosis was present in $21 \%$, inactive in $10 \%$, and healed in $23 \%$ of cases.

There are no comparable figures for the incidence of these various types of tuberculosis in the Bantu non-miner in South Africa. Gough (1960) found that $28.5 \%$ of cases of the nodular type of simple coal-workers' pneumoconiosis in Welsh coal-miners showed naked-eye tuberculous lesions. In this series 43 out of 250 cases $(17 \%)$ showed naked-eye lesions of tuberculosis.

Only one case of bronchogenic carcinoma occurred in 253 cases of simple pneumoconiosis. James (1955) found $5 \cdot 1 \%$ of cases with bronchogenic carcinoma in miners with simple coal-workers' pneumoconiosis and states that it is less frequently found in coalminers than in non-miners; the majority of cases in his mining and non-mining groups were over the age of 50 years.

Chronic cor pulmonale was present in six cases with simple pneumoconiosis in this series. Lavenne (1960) states that $20 \%$ of coal-miners with right heart failure showed the presence of simple pneumoconiosis. There were 17 cases of chronic cor pulmonale in this series.

Progressive Massive Fibrosis.-There were only 17 cases in this series showing this type of lesion. This group is poorly represented as the lungs of fully compensated cases are not usually sent to the South African Pneumoconiosis Bureau for examination. Twelve of these cases were in the 50-59 age group. The length of service varied from six to 40 years. Eight cases showed evidence of tuberculosis, six being active. There were six cases of chronic cor pulmonale, and bronchogenic carcinoma was not observed.

Miscellaneous Respiratory Lesions.-The following were noted.

Pleurisy.-Chronic non-specific pleurisy with tags of fibrous adhesions was found in 259 cases, giving an autopsy incidence of $24 \%$. Evidence of tuberculosis in the hilar glands or lung was present in $50 \%$ of cases. In $62 \%$ of cases the pleurisy was bilateral.

There were nine cases of acute fibrinous pleurisy with no lung lesions. Evidence of tuberculosis in the hilar glands was found in six of these cases, although no histological evidence of tuberculosis was noted in sections of the pleurae.

There were six cases of tuberculous pleurisy showing a fibrino-haemorrhagic exudate and one case of tuberculous empyema.

Bronchiectasis.-Bronchiectasis was noted in four cases. The atelectatic type was present in two cases affecting the middle lobe of the right lung. A diffuse cylindrical or digitate type of bronchiectasis was present in the basal lobes in two cases, one of which showed marked follicular lymphoid hyperplasia in the bronchial walls. Only one case showed the presence of simple pneumoconiosis. 
TABLE 9

INCIDENCE OF VARIOUS TYPES OF PERICARDITIS IN 1,010 COAL-MINERS

\begin{tabular}{l|c|c|c|c|c|c|c|c|}
\hline & Tuberculous & Fibrinous & Suppurative & Chronic Non-specific & Malignant & 1 & 31 \\
\hline $\begin{array}{l}\text { Number of cases } \\
\text { pericarditis }\end{array}$ & 22 & 11 & 51 & 1 \\
\hline
\end{tabular}

Animal Parasitic Lesions of the Lungs.-Bilharzial lesions were noted in eight cases. The lesions were mild, showing an occasional bilharzial follicle or calcified ova in the interstitial tissue with no reaction in relation to them.

Fibrocystic Disease of the Lungs.-There were two cases of fibrocystic disease of the lungs. In one case the lesion affected both lungs, and in the other it was localized to the left apical lobe.

Cardiac Lesions.-There were 170 cases showing evidence of cardiac involvement, giving an autopsy incidence of $16.8 \%$. Lavenne (1960) found the autopsy incidence of heart disease to be $23.7 \%$ in white Welsh coal-miners. Vint (1937) found an autopsy incidence of heart disease in $5.6 \%$ of Kenya natives.

Pericarditis.-Pericarditis was present in 62 cases, giving an autopsy incidence of $6 \cdot 2 \%$ (Becker (1943), $3.5 \%$ ).

The incidence of the various types of pericarditis is shown in Table 9.

From Table 9 it is noted that chronic non-specific adhesive pericarditis constitutes $51 \%$ of all types of pericarditis. The autopsy incidence of chronic nonspecific pericarditis was 3\% (Becker (1943), $4.9 \%$ ). Evidence of tuberculosis in the lungs or hilar glands was found in $80 \%$ of cases with chronic non-specific pericarditis. In no case was infarction of the myocardium the cause of the pericarditis. Tuberculous pericarditis constituted $35 \%$ of all types of pericarditis (Becker (1943), 58\%) and the autopsy incidence was $2 \%$. All cases were of the acute type except one which showed a chronic constrictive pericarditis. Sweeney (1940) found the average autopsy incidence of tuberculous pericarditis to be $1 \%$. Other types of pericarditis were found to be uncommon in this series.

Rheumatic Carditis.-Rheumatic carditis was present in 19 cases, giving an autopsy incidence of $1.8 \%$ (Becker (1943), 3.5\%). The autopsy incidence in the United States varied from less than $1 \%$ to $9 \%$ (Becker, 1943). Rheumatic carditis constituted 11\% of all cardiovascular lesions in this series (Becker (1943), $7 \cdot 7 \%$ ). The average age incidence was 39 years. The commonest valve affected was the aortic valve, and only one case showed superadded bacterial endocarditis.

Cardiovascular Syphilis.-Cardiovascular syphilis was present in 11 cases, giving an autopsy incidence of $1 \%$, and constituted $6.5 \%$ of all cardiovascular lesions (Becker (1943), 12.7\%). There were nine cases of aortic incompetence.

Chronic Cor Pulmonale.-Chronic cor pulmonale was present in 17 cases, giving an autopsy incidence of $1.6 \%$ (Becker (1943), $1.5 \%$ ), and constituted $1 \%$ of all cardiovascular lesions (Becker (1943), 19\%). Dyson (1934) found an incidence of $14 \%$ in anthracite coal-miners. Lavenne (1960) found an autopsy incidence of $23.7 \%$, and $20 \%$ of these coal-miners with right heart failure showed simple pneumoconiosis. In this series progressive massive fibrosis was inadequately represented. Coal-workers' pneumoconiosis was found in 12 cases and six were simple. Wells (1954) states that in early simple pneumoconiosis cor pulmonale occurs frequently but could rarely be attributed to the industrial disease. Lavenne (1960) found cor pulmonale in 83 out of 338 Welsh coal-miners with pneumoconiosis.

Hypertensive Heart Disease.-Hypertensive heart disease was found in 50 cases, giving an autopsy incidence of $5 \%$ (Becker (1943), $8.2 \%$ ), and constituting $29 \%$ of all cardiac lesions; $82 \%$ were due to essential hypertension (Becker, 61\%). Hart and Aslett (1942) stated that during the chronic ambulatory stages the pneumoconiosis found in South Wales coal-miners does not produce a raised blood pressure, certainly not a progressive one.

Myocarditis.-Myocarditis was noted in seven cases; six were of the acute non-specific type and one was suppurative.

Animal Parasitic Lesions.-Only one case of parasitic infestations of the heart was found, a case of cysticercosis.

\section{REFERENCES}

Becker, B. J. P. (1943). Cardio-Vascular Disease in the Bantu and Coloured Races of South Africa. Thesis. University of the Witwatersrand, Johannesburg.

Berman, C. (1935). S. Afr. J. med. Sci., 1, 12

Carnes, W. H. (1942). Bull. Johns Hopk. Hosp., 70101

Chatgidakis, C. B. (1960). Arch. environm. Hith, 1, 17.

Davies, J. N. P. (1948). E. Afr. med. J., 25, 117. 
Duchen, L. W. (1954). S. Afr. J. med. Sci., 19, 65.

Dyson, J. M. (1934). Amer. Heart J. 9, 764.

Frazer, A. E. (1961). Coal Mining in South Africa. 7th Commonwealth Mining and Metallurgical Congress.

Gough, J. (1946). Lancet, 1, 462.

- (1949). Postgrad. med. J., 25, 611.

(1960). In Proceedings of the Pneumoconiosis Conference, Johannesburg, 1959, edited by Orenstein, A. J., pp. 322-324. Churchill, London.

Hart, P. D'Arcy, and Aslett, E. A. (1942). Chronic Pulmonary Disease in South Wales Coalminers. B. Medical Survey. Spec. Rep. Ser. med. Res. Coun. (Lond.), No. 243, pp. 1-202. H.M.S.O. Higginsondon

Hagginson, J. (1951). Cancer (Philad.), 4, 1224

J. R. L. (1955). Brit. J. industr. Med., 12, 87.

Land Thomas, A. J. (1956). Ibid., 13, 24.

Landé, K. E., and Wolff, G. (1941). Amer. Rev. Tuberc., 44, 223.
Lavenne, F. (1960). In Proceedings of the Pneumoconiosis Conference, edited by Orenstein, A. J., pp. 217-219. Churchill, London.

Medlar, E. M. (1955). The Behaviour of Pulmonary Tuberculous Lesions. Amer. Rev. Tuberc., 71, No. 3, pt. 2 (Suppl.).

The Mineral Resources of the Union of South Africa (1959). Department of Mines, Office of the Geological Survey, 4th ed., Government Printer, Pretoria.

Naegeli, O. (1900). Virchows Arch. path. Anat., 160, 426. Quoted by Landé, K. E., and Wolff, G. (1941)

Opie, E. L. (1917). J. exp. Med., 25, 855.

Plumstead, E. P. (1957). Coal in Southern Africa, p. 23. Witwatersrand University Press, Johannesburg.

Schrier, C. F. (1948). Industr. Med., 17, 47.

Sweeney, J. A. (1940). Amer. Heart J., 20, 345.

Todd, T. R. R. (1927). Edinb. med. J., N.S. 34, 127.

Vint, F. W. (1937). E. Afr. med. J., 13, 332.

Wason, I. M. (1922). Quoted by Landé, K. E. and Wolff, G. (1941).

Wells, A. L. (1954). Brit. Heart J., 16, 74 .

\section{THE APRIL (1963) ISSUE}

The April (1963) issue contains the following papers:-

Advancing Frontiers in Industrial Health. L. G. NoRman

Wound Healing and the Dressing. JOHN T. SCALES

A Preliminary Study of Some Health Hazards in the Plasma Jet Process. D. E. Hickish and P. J. R. Challen

Polyester Resin Hazards. L. B. Bourne and F. J. M. Milner

Thermal Comfort in the Hot Humid Tropies of Australia. C. H. Wyndham

Dust and Fibrosis in the Lungs of Coal-workers from the Wigan Area of Lancashire. $\quad$ R. SPINK and G. NAGELSCHMIDT

Estimating Progression of Coal-workers' Simple Pneumoconiosis from Readings of Radiological Categories.

M. E. WISE and P. D. OLDHAM

Effect of Radiographic Technique on Readings of Categories of Simple Pneumoconiosis. M. E. WISE and P. D. Oldham

Occupational Health in Eastern Europe. R. M. MALAN

Miscellanea

Interdigital Pilonidal Sinus due to Pig Bristles. A. C. da RozA

\section{Book Reviews}

A number of copies are still available and may be obtained from the Publishing Manager, British Medical Association, Tavistock Square, W.C.1. price 18s. $6 d$. 